\title{
Economic Load Dispatch Unit Pembangkit Termal Mempertimbangkan Penambahan Pembangkit Tenaga Angin dengan Menggunakan Firefly Algorithm
}

\author{
Ridho Syahrial Ibrahim, Rony Seto Wibowo, Arif Musthofa \\ Jurusan Teknik Elektro - FTI - Institut Teknologi Sepuluh Nopember (ITS) \\ Jl. Arief Rahman Hakim, Surabaya 60111 \\ Email: ronyseto@ee.its.ac.id, arif@ee.its.ac.id
}

\begin{abstract}
Abstrak - Maraknya isu global warming serta keterbatasan sumber daya alam membuat mulai banyaknya dibangun pembangkit-pembangkit listrik dengan renewable energy, salah satunya adalah pembangkit tenaga angin. Pada jurnal ini, firefly algorithm diterapkan untuk mengoptimasi total biaya pembangkitan 2 buah sistem uji, tanpa dan dengan mempertimbangkan penambahan tenaga angin. Hasil simulasi menunjukkan bahwa dengan penambahan pembangkit tenaga angin ke dalam sistem tenaga listrik, total biaya pembangkitan tidak selalu lebih murah. Selain itu, hasil simulasi juga menunjukkan bahwa firefly algorithm sebagai metode optimasi dapat menyelesaikan permasalahan economic load dispatch (ELD) lebih baik dibandingkan metode lain yang sudah dilakukan, yaitu particle swarm optimization (PSO), bat algorithm (BA), biogeography-based optimization (BBO) dan plant growth simulation algorithm (PGSA) dengan persentase selisih nilai penghematan total biaya berkisar antara $0.32 \%$ (\$50) hingga 9.27\% (\$11884).
\end{abstract}

Kata Kunci : economic load dispatch, firefly algorithm, pembangkit tenaga angin.

\section{DAFTAR SIMBOL DAN SINGKATAN}

$a_{i}, b_{i}, c_{i}$ koefisien fuel cost pembangkit termal ke-i

c scale factor dari Weibull distribution

$C G_{i} \quad$ biaya pembangkitan pembangkit termal ke-i

$C_{d_{w_{j}}} \quad$ direct cost pembangkit tenaga angin ke-j

$C_{p_{w_{j}}} \quad$ penalty cost pembangkit tenaga angin ke-j

$C_{r_{w_{j}}} \quad$ reserve cost pembangkit tenaga angin ke-j

$C W_{j} \quad$ biaya pembangkitan unit tenaga angin ke-j

CT total biaya pembangkitan

$f_{w}(w) \quad$ probability density function untuk $\mathrm{w}$

$k \quad$ shape factor dari Weibull distribution

$K_{d_{w_{j}}} \quad$ koefisien direct cost pembangkit tenaga angin ke-j

$K_{p_{w_{j}}} \quad$ koefisien penalty cost pembangkit tenaga angin ke-j

$K_{r_{w_{j}}} \quad$ koefisien reserve cost pembangkit tenaga angin ke-j

$M \quad$ jumlah pembangkit termal

$N \quad$ jumlah pembangkit tenaga angin

$P_{d} \quad$ permintaan daya aktif $(M W)$

$P_{i} \quad$ daya yang dibangkitkan pembangkit termal ke-i
$P_{i_{\text {maks }}}$ daya maksimum pembangkitan pembangkit termal ke-i

$P_{i_{\text {min }}} \quad$ daya minimum pembangkitan pembangkit termal ke-i

$\operatorname{Pr}\{E\} \quad$ probabilitas kejadian $\mathrm{E}$

$v \quad$ kecepatan angin

$v_{\text {in }} \quad$ kecepatan angin cut-in

$v_{\text {out }} \quad$ kecepatan angin cut-out

$v_{r} \quad$ kecepatan angin rated

$w_{j} \quad$ daya yang dibangkitkan pembangkit tenaga angin ke-j

$w_{r} \quad$ daya rated pembangkit tenaga angin

\section{PENDAHULUAN}

$\mathrm{H}_{\mathrm{n}}^{\mathrm{n}}$ INGA saat ini, pembangkit listrik jenis termal masih mendominasi dikarenakan mudah dalam pengoperasiannya serta output pembangkit yang dapat diatur sesuai kebutuhan. Namun, menipisnya kuantitas bahan bakar minyak dan batu bara memaksa kita untuk mencari sumber energi alternatif lain. Salah satunya adalah tenaga angin yang merupakan renewable energy dan low cost. Sifat natural angin yang kecepatannya berubah-ubah setiap interval waktunya membuat output dari pembangkit tenaga angin tidak dapat stabil. Hal ini memberikan tantangan baru pada permasalahan economic load dispatch karena faktor ketidakstabilan ini seharusnya turut dipertimbangkan pada saat perencanaan pembangkitan dayanya.

Jurnal ini akan membahas tentang dampak penambahan pembangkit tenaga angin pada sistem tenaga listrik terhadap total biaya pembangkitan. Permodelan economic load dispatch dengan penambahan pembangkit tenaga angin akan ditunjukkan pada bab 2. Pada bab 3 akan dibahas pengimplementasian firefly algorithm untuk penyelesaian permasalahan economic load dispatch. Sedangkan hasil simulasi akan ditunjukkan pada bab 4.

\section{FORMULASI ECONOMIC LOAD DISPATCH DENGAN PENAMBAHAN PEMBANGKIT TENAGA ANGIN}

Pada dasarnya economic load dispatch unit pembangkit termal dengan penambahan pembangkit tenaga angin memiliki tujuan atau objective function untuk memperoleh biaya pembangkitan paling optimal pada suatu waktu dimana semua pembangkit dianggap berada pada status on duty dan sesuai batasan atau constraints [1]. 


\section{A. Objective Function}

Objective function dari economic load dispatch dengan penambahan pembangkit tenaga angin adalah untuk mencari biaya paling optimal dan minimal dari suatu sistem tenaga listrik dan ditunjukkan pada persamaan (1).

$$
\min (C T)=\sum_{i=1}^{M} C G_{i}+\sum_{j=1}^{N} C W_{j}
$$

\section{B. Constraints}

Daya yang dibangkitkan oleh setiap pembangkit termal maupun pembangkit tenaga angin haruslah tidak kurang atau lebih dari kapasitas minimum dan maksimum pembangkitannya. Inequality constraints pada permasalahan ini dapat dilihat pada persamaan (2) dan (3).

$$
\begin{gathered}
P_{i_{\text {min }}} \leq P_{i} \leq P_{i_{\text {maks }}} \\
0<w_{j} \leq w_{j_{\text {rated }}}
\end{gathered}
$$

\section{Fungsi Biaya Unit Pembangkit Termal}

Fungsi biaya unit pembangkit termal yang digunakan bersifat smooth, non-convex, tanpa mempertimbangkan emisi pembangkitan atau valve loading effect yang ditunjukkan pada persamaan (4).

$$
C G_{i}=a_{i}+b_{i}\left(P_{i}\right)+c_{i}\left(P_{i}\right)^{2}
$$

\section{Fungsi Biaya Unit Pembangkit Tenaga Angin}

Fungsi biaya pembangkit tenaga angin ke-j dituliskan pada persamaan (5)[2].

$$
C W_{j}=C_{d_{w_{j}}}+C_{p_{w_{j}}}+C_{r_{w_{j}}}
$$

Pada persamaan (5), variabel pertama mewakili direct cost pembangkitan dari pembangkit tenaga angin. Direct cost ini bersifat linear dengan daya yang dibangkitkan pembangkit, dituliskan pada persamaan (6). Sedangkan variabel kedua merupakan penalty cost akibat underestimation, karena tidak menggunakan semua tenaga angin yang tersedia. Biasanya daya yang terbuang ini disalurkan ke dummy resistor atau baterai. Jika operator adalah pemilik pembangkit tenaga angin, maka kedua variabel tersebut diabaikan. Sedangkan variabel yang ketiga adalah reserve cost akibat overestimation daya pembangkit tenaga angin, sehingga operator memesan daya pada grid. Jika pembangkit tenaga angin dimiliki oleh operator maka variabel direct cost dan reserve cost dapat diabaikan.

$$
C_{d_{w_{j}}}=K_{d_{w_{j}}}\left(w_{j}\right)
$$

Sedangkan penalty cost ditunjukkan pada persamaan (7).

$$
\begin{aligned}
C_{p_{w_{j}}} & =K_{p_{w_{j}}}\left(W_{a v_{j}}-w_{j}\right) \\
& =K_{p_{w_{j}}}\left(s_{1}+s_{2}\right)
\end{aligned}
$$

Dimana

$s_{1}=w_{j} \times \operatorname{Pr}\left(W=w_{r}\right)$

$$
=w_{r}-w_{j}\left\{\exp \left[-\left(\frac{v_{\text {in }}}{c}\right)^{k}\right]-\exp \left[-\left(\frac{v_{\text {out }}}{c}\right)^{k}\right]\right\}
$$

Dan

$$
s_{2}=\int_{w_{j}}^{w_{r}}\left(w-w_{j}\right) f w(w) d w
$$

Reserve cost dinyatakan dengan persamaan (10),

$$
\begin{aligned}
C_{r_{w_{j}}} & =K_{r_{w_{j}}}\left(w_{j}-W_{a v_{j}}\right) \\
& =K_{r_{w_{j}}}\left(s_{3}+s_{4}\right)
\end{aligned}
$$

Dimana

$$
\begin{aligned}
s_{3} & =w_{j} \times P(W=0) \\
& =w_{j}\left\{1-\exp \left[-\left(\frac{v_{\text {in }}}{c}\right)^{k}\right]+\exp \left[-\left(\frac{v_{\text {out }}}{c}\right)^{k}\right]\right\}
\end{aligned}
$$

Dan

$$
s_{4}=\int_{0}^{w_{j}}\left(w_{j}-w\right) f w(w) d w
$$

Daya output pembangkit tenaga angin tergantung pada kecepatan angin. Pembangkit tenaga angin tidak mengeluarkan daya saat kecepatan angin kurang dari $v_{i n}$ dan saat kecepatan angin lebih besar dari $v_{\text {out }}$. Pembangkit tenaga angin mulai membangkitkan daya secara linear saat kecepatan angin berada di range antara $v_{\text {in }}$ dan $v_{r}$. Saat kecepatan angin berada di range $v_{r}$ dan $v_{\text {out }}$, maka daya output pembangkit tenaga angin bersifat konstan dengan nilai sebesar kapasitasnya, yaitu $w_{r}$. Karakterisitik ini dapat diplot secara umum dan dapat dilihat pada gambar 1 .

$$
\mathrm{P}
$$

(MW)

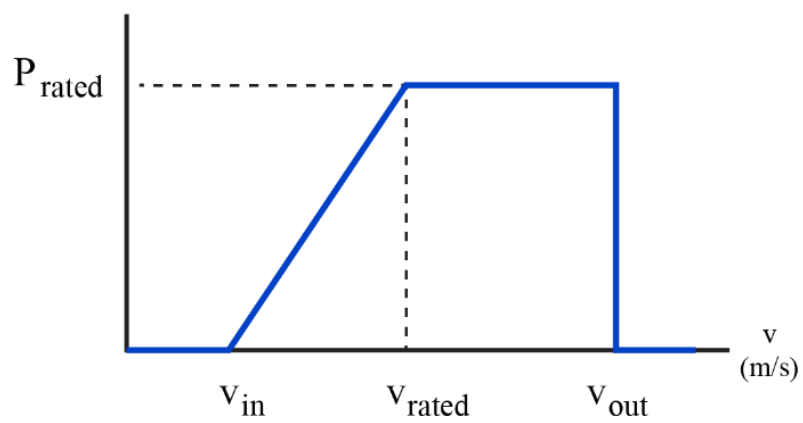

Gambar 1. Karakteristik input-output unit pembangkit tenaga angin

Dengan mengabaikan ketidaklinearan yang nilainya relatif kecil pada bagian kontinyu, maka daya output pembangkit tenaga angin dapat dinyatakan dengan persamaan (13), (14), dan (15) [2].

$$
\begin{array}{lrrr}
w & =0 & \text { untuk } & v<v_{\text {in }} \text { dan } v>v_{\text {out }} \\
w=w_{r} \frac{v-v_{\text {in }}}{v_{r}-v_{\text {in }}} & \text { untuk } & v_{\text {in }} \leq v \leq v_{r} \\
w=w_{r} & \text { untuk } & v_{r} \leq v \leq v_{\text {out }}
\end{array}
$$

Sifat kecepatan angin yang tidak stabil tiap interval waktunya memberikan permasalahan tersendiri dalam perencanaan pembangkitan dayanya. Penelitian yang pernah dilakukan pada [3], menyatakan bahwa rata-rata 
pendistribusian kecepatan angin mengikuti Weibull distribution, dengan cumulative distribution function $(C D F)$ ditunjukkan pada persamaan (16).

$$
F_{V}(v)=1-\exp \left[-\left(\frac{v}{c}\right)^{k}\right]
$$

Dengan menurunkan persamaan (16) didapatkan probability density function $(P D F)$ untuk kecepatan angin dari Weibull distribution yang dinyatakan pada persamaan (17).

$$
f_{V}(v)=\frac{k}{c}\left(\frac{v}{c}\right)^{k-1} \exp \left[-\left(\frac{v}{c}\right)^{k}\right]
$$

Pada Weibull distribution, terdapat dua bagian, yaitu bagian kontinyu dan bagian diskrit. Pada interval kontinyu yaitu saat $v_{\text {in }} \leq V \leq v_{r}, P D F$ dari $\mathrm{W}$ ditunjukkan pada persamaan (18).

$$
\begin{aligned}
f w(w) & =\frac{k h v_{i n}}{w_{r} c}\left[\frac{\left(1+\frac{h w}{w_{r}}\right) v_{i n}}{c}\right]^{k-1} \\
& \times \exp \left\{-\left[\frac{\left(1+\frac{h w}{w_{r}}\right) v_{i n}}{c}\right]^{k}\right\}
\end{aligned}
$$

Keterangan,

$h=\left(\frac{v_{r}}{v_{\text {in }}}\right)-1 \quad$ rasio range linear dari kecepatan angin terhadap kecepatan angin cut-in

Perlu diperhatikan terdapat bagian diskrit yaitu saat $W=$ 0 dan $W=w_{r}$. Probabilitas saat $W=0$ ditunjukkan pada persamaan (19).

$$
\begin{aligned}
\operatorname{Pr}\{W=0\} & =\operatorname{Pr}\left(V<v_{\text {in }}\right)+\operatorname{Pr}\left(V \geq v_{\text {out }}\right) \\
& =F_{V}\left(v_{\text {in }}\right)+\left(1-F_{V}\left(v_{\text {out }}\right)\right) \\
=1 & -\exp \left[-\left(\frac{v_{\text {in }}}{c}\right)^{k}\right]+\exp \left[-\left(\frac{v_{\text {out }}}{c}\right)^{k}\right]
\end{aligned}
$$

Dan probabilitas saat $W=w_{r}$, ditunjukkan pada persamaan (20).

$$
\begin{aligned}
P_{r}\left\{W=w_{r}\right\} & =\operatorname{Pr}\left(v_{r} \leq V<v_{\text {out }}\right) \\
& =F_{V}\left(v_{\text {out }}\right)-F_{V}\left(v_{r}\right) \\
& =\exp \left[-\left(\frac{v_{r}}{c}\right)^{k}\right]-\exp \left[-\left(\frac{v_{\text {out }}}{c}\right)^{k}\right]
\end{aligned}
$$

\section{FIREFLY ALGORITHM SEBAGAI METODE PENYELESAIAN PERMASALAHAN ECONOMIC LOAD DISPATCH}

Firefly algorithm adalah algoritma metaheuristik yang terinspirasi dari perilaku kedipan kunang-kunang [4]. Dikembangkan oleh Dr. Xin She Yang di Cambridge University pada tahun 2007, firefly algorithm memiliki aturan-aturan sebagai berikut:

1. Semua kunang-kunang berjenis kelamin tunggal, sehingga seekor kunang-kunang akan tertarik terhadap kunang-kunang lain tanpa mempedulikan jenis kelaminnya.

2. Daya tarik (attractiveness) bernilai proporsional dengan tingkat kecerahannya (light intensity). Sehingga seekor kunang-kunang akan bergerak menuju kunang-kunang lain yang lebih terang. Daya tarik dan tingkat kecerahan akan berkurang dengan bertambahnya jarak antar keduanya. Jika di antara keduanya tidak ada yang lebih cerah, maka mereka akan bergerak secara acak.

3. Tingkat kecerahan seekor kunang-kunang dipengaruhi atau ditentukan oleh fungsi objektif (objective function) yang akan dioptimasi.

\section{A. Pembangkitan Posisi Awal Populasi Kunang-Kunang}

Pembangkitan populasi kunang-kunang awal menggunakan metode pembangkitan acak. Namun pembangkitan tersebut tidak boleh melebihi constraints yaitu daya minimum dan maksimum pembangkit. Pembangkitan populasi kunang-kunang awal dirumuskan pada persamaan (21).

$$
f_{i, k}=P_{\text {min }, k}+\left(P_{\text {max }, k}-P_{\text {min }, k}\right) \times \text { rand }
$$

Kemudian dari populasi awal yang telah dibangkitkan tersebut, dimasukkan ke fungsi biaya masing-masing pembangkit, dan mencari total biaya pembangkitan paling murah sementara (solution).

\section{B. Light Intensity, Attractiveness, dan Pergerakan} Kunang-Kunang

Dalam firefly algorithm, light intensity menentukan tingkat kelayakan suatu populasi sebagai solusi. Untuk permasalahan economic load dispatch, karena kita mencari nilai minimum, maka light intensity berbanding terbalik dengan total biaya pembangkitan. Sehingga total biaya pembangkitan paling murah merupakan populasi kunangkunang yang paling terang. Light intensity suatu populasi dapat dirumuskan pada persamaan (22).

$$
\text { light intensity } y_{i}=\frac{1}{1+C T_{i}}
$$

Attractiveness seekor kunang-kunang terhadap kunangkunang lain tergantung dari jarak antara keduanya. Semakin dekat keduanya, maka daya tarik semakin besar. Jarak dan daya tarik (attractiveness) seekor kunang-kunang i terhadap kunang-kunang paling terang $\mathrm{j}$ didefinisikan pada persamaan (23) dan (24).

$$
\begin{gathered}
r_{i, k}=\left|f_{i, k}-f_{j, k}\right| \\
\beta_{i, k}=\beta_{0} \exp \left(-\gamma r_{i, k}\right)^{2}
\end{gathered}
$$

Pergerakan kunang-kunang i,k menuju kunang-kunang yang lebih terang (pembaruan nilai kunang-kunang) dituliskan pada persamaan (25).

$$
f_{i, k}=f_{i, k}+\beta_{0} \exp \left(-\gamma r_{i, k}^{2}\right) *\left(f_{j, k}-f_{i, k}\right)+\operatorname{rand} \times \alpha
$$

\section{Constraints Handling}

Terdapat 3 tahapan untuk mengatasi constraints pada penelitian ini. Pseudo-code untuk penyelesaian constraints ini dapat dilihat pada gambar 2. 


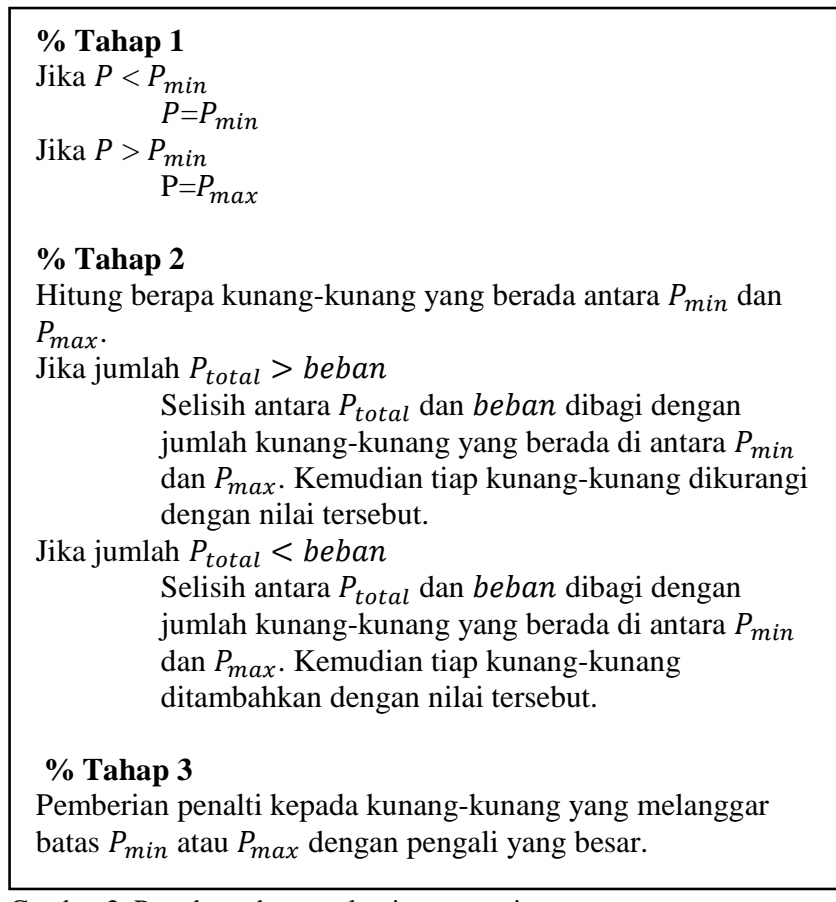

Gambar 2. Pseudo-code penyelesaian constraints

\section{SIMULASI DAN ANALISIS}

Dua buah sistem pengujian digunakan, dimana untuk setiap sistem uji dilakukan optimasi dengan dan tanpa penambahan pembangkit tenaga angin guna mengetahui dampak penambahan pembangkit tenaga angin pada total biaya pembangkitan. Pengaruh faktor kepemilikan pembangkit tenaga angin terhadap total biaya pembangkitan turut disajikan pada jurnal ini. Parameter firefly algorithm yaitu $\alpha, \beta$, dan $\gamma$ didapat dari [5] dengan nilai $0.5,1$, dan 1 .

Simulasi akan dijalankan pada sistem komputasi dengan spesifikasi yang ditunjukkan pada tabel 1. Untuk setiap sistem uji, program dieksekusi sebanyak 20 kali untuk menjamin kualitas dari hasil optimasi.

Tabel 1.

Sistem komputasi yang digunakan

\begin{tabular}{ccc}
\hline \hline No & Parameter & Spesifikasi \\
\hline 1 & Prosessor & Intel ${ }^{\circledR}$ core ${ }^{\mathrm{TM}} \mathrm{i} 3-2350 \mathrm{M}$ \\
2 & Kecepatan prosessor & $2.30 \mathrm{GHz}$ \\
3 & Random Access & $4 \mathrm{~GB}$ \\
4 & Memory $($ RAM $)$ & Windows 10.1 Pro 64-bit \\
5 & Compiler & Matlab R2016B \\
\hline \hline
\end{tabular}

\section{A. Sistem Uji 1}

Sistem Uji 1 terdiri dari 6 unit pembangkit termal dan sebuah pembangkit tenaga angin. Data pembangkit termal didapat dari [6]. Sedangkan data pembangkit tenaga angin didapat dari [7]. Hasil optimasi akan dibandingkan dengan $P S O$ dan $B A$ yang telah dilakukan [7].
Tabel 2.

Hasil optimasi sistem uji 1

\begin{tabular}{|c|c|c|c|c|c|c|c|}
\hline \multirow{2}{*}{\multicolumn{2}{|c|}{ Unit }} & \multicolumn{3}{|c|}{ Tanpa Tenaga Angin } & \multicolumn{3}{|c|}{ Dengan Tenaga Angin } \\
\hline & & PSO & $\mathbf{B A}$ & FA & PSO & $\mathbf{B A}$ & FA \\
\hline$P_{1}$ & \multirow{5}{*}{$\sum$} & 440,58 & 442,43 & 446,73 & 429,29 & 403,72 & 429,13 \\
\hline$P_{2}$ & & 167,90 & 173,71 & 171,28 & 176,28 & 171,82 & 158,51 \\
\hline$P_{3}$ & & 258,19 & 262,34 & 264,09 & 257,61 & 233,13 & 250,43 \\
\hline$P_{4}$ & & 117,25 & 118,61 & 125,20 & 98,71 & 147,89 & 111,39 \\
\hline$P_{5}$ & & 182,66 & 182,66 & 172,12 & 159,46 & 163,18 & 156,64 \\
\hline$P_{6}$ & & 83,16 & 83,16 & 83,58 & 87,60 & 91,96 & 66,89 \\
\hline$P_{W}$ & & - & - & - & 54,05 & 51,28 & 90,01 \\
\hline$C G$ & & 15282 & 15276 & 15276 & 14570 & 14623 & 14224 \\
\hline$C_{d}$ & & - & - & - & 432 & 410 & 720 \\
\hline$C_{p}$ & (્) & - & - & - & 206 & 194 & 158 \\
\hline$C_{r}$ & & - & - & - & 260 & 256 & 315 \\
\hline$C T$ & & 15282 & 15276 & 15276 & 15483 & 15468 & 15418 \\
\hline
\end{tabular}

Tabel 3.

Perbandingan hasil optimasi sistem uji 1 memperhitung-kan faktor kepemilikan pembangkit tenaga angin

\begin{tabular}{|c|c|c|c|}
\hline \multirow{2}{*}{\multicolumn{2}{|c|}{ Unit }} & \multicolumn{2}{|c|}{ Status Kepemilikian Tenaga Angin } \\
\hline & & Private Sector & Operator \\
\hline$P_{1}$ & \multirow{7}{*}{$\sum$} & 429,13 & 379,98 \\
\hline$P_{2}$ & & 158,51 & 122,09 \\
\hline$P_{3}$ & & 250,43 & 212,20 \\
\hline$P_{4}$ & & 111,39 & 150,00 \\
\hline$P_{5}$ & & 156,64 & 113,73 \\
\hline$P_{6}$ & & 66,89 & 120,00 \\
\hline$P_{W}$ & & 90,01 & 165,00 \\
\hline$C G$ & \multirow{5}{*}{ (્) } & 14224,02 & 13340,17 \\
\hline$C_{d}$ & & 720,11 & - \\
\hline$C_{p}$ & & 158,48 & - \\
\hline$C_{r}$ & & 315,03 & 829,51 \\
\hline$C T$ & & 15418 & 14170 \\
\hline
\end{tabular}

Dari tabel 2 dapat kita lihat bahwa biaya total hasil optimasi pada sistem uji 1 tanpa pembangkit tenaga angin menggunakan firefly algorithm adalah \$15276. Total biaya optimal tersebut sama dengan total biaya yang diperoleh dari optimasi menggunakan bat algorithm yang lebih efisien dibandingkan hasil optimasi menggunakan particle swarm optimization.

Sedangkan pada saat terdapat pembangkit tenaga angin pada sistem uji 1, total biaya pembangkitan menggunakan firefly algorithm adalah sebesar $\$ 15418$, berselisih $\$ 50$ dari hasil optimasi bat algorithm yang lebih efisien dari optimasi particle swarm optimization yang menghasilkan \$15483. Dengan mengamati tabel 2 dapat dilihat bahwa kesemua metode yang dikomparasi menghasilkan total biaya tanpa pembangkit tenaga angin lebih murah daripada dengan mengintegrasikannya ke dalam sistem.

Hasil optimasi pada tabel 3 menunjukkan bahwa faktor kepemilikan pembangkit tenaga angin memberikan dampak signifikan dari total biaya pembangkitan. Dengan operator sebagai pemilik pembangkit tenaga angin, biaya pembangkitan adalah $\$ 14170$ atau lebih murah $8,1 \%$ dari total biaya pembangkitan dengan private sector sebagai 
pemilik. Dikarenakan operator tidak dikenakan biaya untuk pembangkitan langsung dan penalty cost, maka pembangkit tenaga angin dapat dimaksimalkan hingga kapasitas maksimumnya yaitu $165 \mathrm{MW}$ dengan overestimation cost sebesar $\$ 829,51$.

\section{B. Sistem Uji 2}

Sistem Uji 2 terdiri dari 40 unit pembangkit termal dan sebuah pembangkit tenaga angin. Data pembangkit termal didapat dari [8]. Sedangkan data pembangkit tenaga angin didapat dari [9]. Hasil optimasi akan dibandingkan dengan $B B O$ dan PGSA yang telah dilakukan [9].

Tabel 4.

Hasil optimasi sistem uji 2

\begin{tabular}{|c|c|c|c|c|c|}
\hline \multirow{2}{*}{ Unit } & \multicolumn{3}{|c|}{ Tanpa Tenaga Angin } & \multicolumn{2}{|c|}{ Dengan Tenaga Angin } \\
\hline & BBO & PGSA & FA & PGSA & FA \\
\hline$P_{1}$ & 80,00 & 82,70 & 114,00 & 69,43 & 114,00 \\
\hline$P_{2}$ & 120,00 & 77,86 & 114,00 & 88,08 & 114,00 \\
\hline$P_{3}$ & 190,00 & 110,62 & 120,00 & 76,34 & 81,10 \\
\hline$P_{4}$ & 42,00 & 171,62 & 190,00 & 89,06 & 114,59 \\
\hline$P_{5}$ & 42,00 & 89,88 & 97,00 & 78,80 & 97,00 \\
\hline$P_{6}$ & 140,00 & 126,54 & 140,00 & 128,58 & 106,30 \\
\hline$P_{7}$ & 300,00 & 293,23 & 300,00 & 112,82 & 285,09 \\
\hline$P_{8}$ & 300,00 & 291,31 & 300,00 & 282,63 & 300,00 \\
\hline$P_{9}$ & 300,00 & 299,16 & 300,00 & 278,71 & 300,00 \\
\hline$P_{10}$ & 276,81 & 264,66 & 130,00 & 189,48 & 130,00 \\
\hline$P_{11}$ & 317,61 & 209,77 & 94,00 & 155,30 & 94,00 \\
\hline$P_{12}$ & 304,17 & 351,30 & 94,08 & 208,77 & 94,00 \\
\hline$P_{13}$ & 446,13 & 399,90 & 125,01 & 399,59 & 125,00 \\
\hline$P_{14}$ & 493,10 & 396,82 & 271,95 & 404,02 & 125,56 \\
\hline$P_{15}$ & 500,00 & 467,01 & 264,55 & 234,41 & 125,14 \\
\hline$P_{16}$ & 500,00 & 323,54 & 268,40 & 243,06 & 125,16 \\
\hline$P_{17}$ & 500,00 & 415,73 & 500,00 & 338,51 & 386,13 \\
\hline$P_{18}$ & 500,00 & 421,17 & 500,00 & 383,02 & 391,11 \\
\hline$P_{19} \sum$ & 500,00 & 467,07 & 550,00 & 537,28 & 409,56 \\
\hline$P_{20}$ & 550,00 & 461,11 & 550,00 & 256,55 & 408,58 \\
\hline$P_{21}$ & 550,00 & 455,27 & 550,00 & 355,83 & 550,00 \\
\hline$P_{22}$ & 550,00 & 533,63 & 550,00 & 545,33 & 550,00 \\
\hline$P_{23}$ & 550,00 & 445,27 & 550,00 & 476,64 & 550,00 \\
\hline$P_{24}$ & 550,00 & 546,65 & 550,00 & 482,30 & 550,00 \\
\hline$P_{25}$ & 550,00 & 476,21 & 550,00 & 456,57 & 550,00 \\
\hline$P_{26}$ & 550,00 & 511,96 & 550,00 & 532,82 & 550,00 \\
\hline$P_{27}$ & 550,00 & 29,39 & 10,00 & 59,86 & 10,00 \\
\hline$P_{28}$ & 12,40 & 49,04 & 10,00 & 48,52 & 10,00 \\
\hline$P_{29}$ & 12,40 & 34,18 & 10,00 & 20,84 & 10,00 \\
\hline$P_{30}$ & 12,40 & 91,43 & 97,00 & 96,60 & 97,00 \\
\hline$P_{31}$ & 20,00 & 188,08 & 190,00 & 124,09 & 190,00 \\
\hline$P_{32}$ & 20,00 & 116,06 & 190,00 & 134,42 & 190,00 \\
\hline$P_{33}$ & 20,00 & 158,53 & 190,00 & 162,53 & 190,00 \\
\hline$P_{34}$ & 20,00 & 145,84 & 200,00 & 181,78 & 200,00 \\
\hline$P_{35}$ & 18,00 & 166,80 & 200,00 & 169,62 & 200,00 \\
\hline$P_{36}$ & 18,00 & 190,29 & 200,00 & 172,38 & 200,00 \\
\hline$P_{37}$ & 20,00 & 95,89 & 110,00 & 31,14 & 110,00 \\
\hline
\end{tabular}

\begin{tabular}{|c|c|c|c|c|c|}
\hline$P_{38}$ & 25,00 & 70,08 & 110,00 & 63,78 & 110,00 \\
\hline$P_{39}$ & 25,00 & 98,67 & 110,00 & 90,57 & 110,00 \\
\hline$P_{40}$ & 25,00 & 375,47 & 550,00 & 498,73 & 416,22 \\
\hline$P_{W}$ & - & - & - & 54,05 & 90,01 \\
\hline$C G$ & 143925 & 130927 & 118660 & 11664 & 104817 \\
\hline$C_{d}$ & - & - & - & 6825 & 6766 \\
\hline 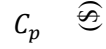 & - & - & - & 242 & 988 \\
\hline$C_{r}$ & - & - & - & 4580 & 3835 \\
\hline$C T$ & 143925 & 130927 & 118660 & 128292 & 116408 \\
\hline
\end{tabular}

Tabel 5.

Perbandingan hasil optimasi sistem uji 2 memperhitung-kan faktor kepemilikan pembangkit tenaga angin

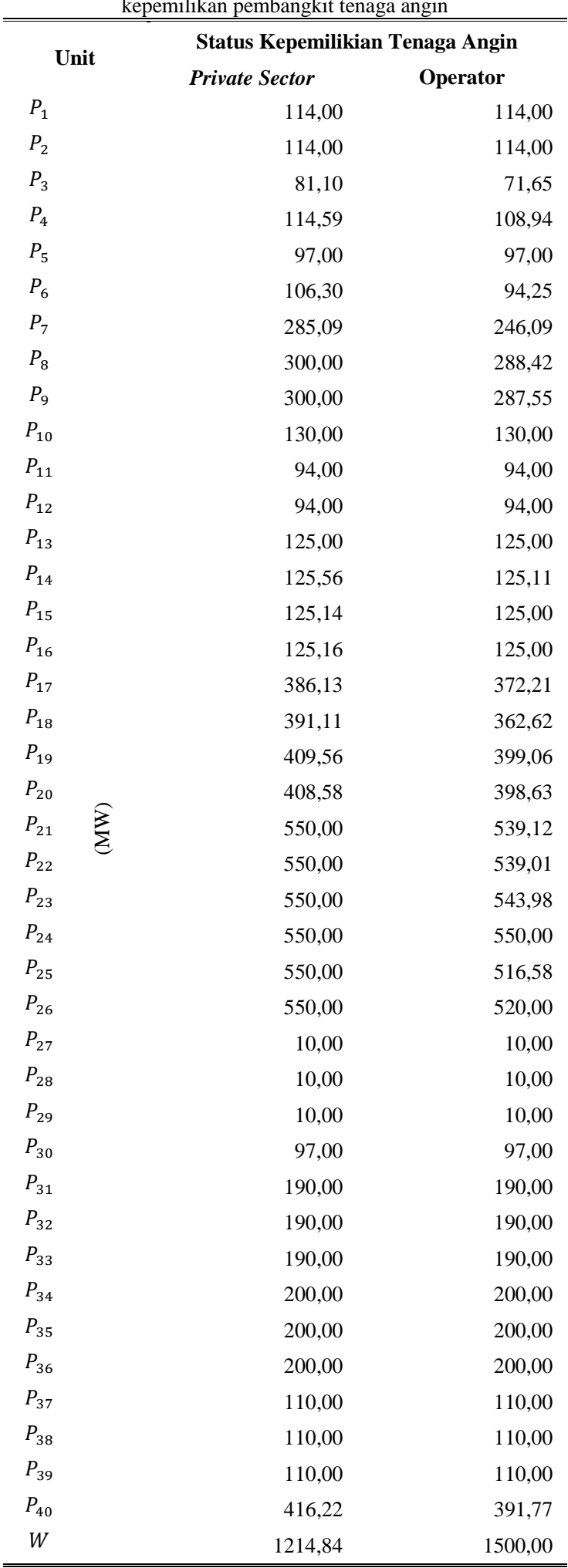




\begin{tabular}{lrrr}
\hline \hline$C G$ & 104817 & 102083 \\
$C_{d}$ & 6766 & - \\
$C_{p}$ & $\approx$ & 988 & - \\
$C_{r}$ & 3835 & 5279 \\
$C T$ & 116408 & 107362 \\
\hline \hline
\end{tabular}

Dari tabel hasil percobaan sistem uji 2, dapat kita lihat bahwa total biaya pembangkitan dengan pembangkit tenaga angin dengan firefly algorithm lebih murah jika dibandingkan dengan tidak menambahkannya ke dalam sistem. Hal tersebut sama dengan hasil yang diperoleh dari plant growth simulation algorithm. Hanya saja selisih hasil optimasi total biaya kedua metode tersebut cukup besar, yaitu $\$ 11884$ atau sekitar 9,26\%, dimana firefly algorithm lebih efisien yaitu sebesar \$116408.

Dari tabel 5, terlihat bahwa total biaya pembangkitan dengan operator sebagai pemilik pembangkit tenaga angin lebih murah $\$ 9046$ atau 7,8 \% dari total biaya dengan private sector sebagai pemilik. Selain itu, dengan tidak adanya biaya pembangkitan dan biaya penalti, maka perencanaan pembangkitan daya dari pembangkit tenaga angin pun dapat dimaksimalkan hingga $100 \%$ dari kapasitasnya yaitu 1500 MW.

\section{KESIMPULAN}

Setelah dilakukan simulasi economic load dispatch dengan penambahan pembangkit tenaga angin, kita dapat menarik beberapa kesimpulan sebagai berikut.

1. Hasil pengujian menunjukkan bahwa metode firefly algorithm mampu menyelesaikan perhitungan economic load dispatch dengan penambahan pembangkit tenaga angin dengan menjaga batasan-batasan seperti equalitity constraints dan inequalitity constraints. Dengan membandingkan hasil optimasi dari metode kecerdasan buatan lain seperti bat algorithm, particle swarm optimization dan plant growth simulation algorithm, hasil optimasi dengan menggunakan firefly algorithm lebih efisien untuk sebagian besar kasus.

2. Penambahan pembangkit tenaga angin ke dalam sistem tidak selalu menurunkan total biaya pembangkitan. Jika pembangkit tenaga angin dimiliki oleh private sector, maka koefisien direct cost dan penalty cost, yang diperoleh sesuai kesepakatan antara operator dan private sector, sangat berpengaruh terhadap perencanaan pembangkitan dayanya.

3. Status kepemilikan pembangkit tenaga angin turut berpengaruh dalam perencanaan pembangkitan daya. Dengan pengasumsian koefisien reserve cost bernilai sama, maka jika pembangkit dimiliki oleh operator, maka operator dapat memaksimalkan pembangkit tenaga angin hingga kapasitas ratednya.

\section{DAFTAR PUSTAKA}

[1] Allen J. Wood, Bruce F. Wollenberg, "Power Generation, Operation, and Control : Second Edition”, New York : Wiley, 1996.

[2] J. Hetzer, and D. C Yu, "An Economic Dispatch Model Incorporatig Wind Power", IEEE Trans. On Energy Covers., vol. 23, no2, pp. 603611, Juni 2008.

[3] I. G. Damousisi, M. C. Alexiadis, J. B. Theocharis, P. S. Dokopoulos, "A Fuzzy Model for Wind Speed Prediction and Power Generation in
Wind Parks Using Spatial Correlation", IEEE Trans. Energy Convers. vol. 19, no.2, pp. 352-3361, Juni 2004

[4] Yang X. S., "Nature-Inspired Metaheuristic Algorithms : Second Edition", United Kingdom : Luniver Press, 2010.

[5] Yang. X. S, "Cuckoo Search and Firefly Algorithm : Theory and Applications", London : Springer, 2014

[6] Z.L. Gaing, "Particle Swarm Optimization to Solving the Economic Dispatch Considering The Generator Constraints". IEEE. Trans. Power Syst., vol 18, No. 3, pp. 1187-1195, Agustus 2003.

[7] Jose J. T., "Economic Load Dispatch Including Wind Power Using Bat Algorithm". International Conference on Advances in Electrical Engineering (ICAEE), Januari 2014.

[8] Sinha N., Chakrabarti R., Chattopadhyay P. K., "Evolutionary Programming Techniques for Economic Load Dispatch", IEEE Trans. Evolutionary Computation, vol. 7, no.1, pp. 83-94, Februari 2003.

[9] Jadhav H. T., Bhandari H., Dalal Y., Roy R., "Economic Load Dispatch Including Wind Power Using Plant Growth Simulation Algorithm”, IEEE Environment and Electrical Engineering, Juni 2012. 